Ashinova Zh.Y., Dautbayeva N.S.

Japanese identity through the eyes of Japanese writers (II half of XX century)

Ашинова Ж.Е., Ааутбаева Н.С.

Жапон жазушыкары көзқарасындағы жапон бірегейлігі (XX ғасырдың II жартысы)

Ашинова Ж.Е, Ааутбаева Н.С.

Японская идентичность глазами японских писателей (II половина XX века)
Japanese national identity have been changed under the influence of other countries. The crises, that have occurred in the country, threatened the traditional identity of the Japanese people. Especially actively started to study identity in the postwar years. At this time, developed classical literature. It became popular to write real and negative aspects of post-war lives of ordinary Japanese people. Many writers of the time such as Kenzaburo Oe, Shintaro Ishihara, Yamakawa Macao, Yukio Mishima, showed in his works psychological changes a person, his experience of the defeat in the war, its goals and assessment of what is happening around. This article describes the most bright works in which you can find reflection of the Japanese after war social life and understanding the identity of Japanese writers.

Key words: Japanese identity, Japanese literature, post-war Japan.

Жапон ұлттық бірегейлігі басқа елдердің ықпалымен талай рет өзгерістерге ұшырап отырған. Елде орын алып отырған АағАарыстар жергілікті халықтың Аәстүрлі бірегейлігіне қатер төнАіріп отырған кезеңдер де болған. Әсіресе екінші дүниежүзілік соғыстан кейінгі жылдары бірегейлік мәселесі белсенді зерттеле бастады. Сонымен қатар бұл кезеңде классикалық әдебиет тез дамыды. Соғыстан кейінгі қарапайым жапондықтар өмірінің шынайы және жағымсыз жақтарын жазу кеңінен танымал болды. Сондай-ақ, Оэ КэнАзабуро, Исихара Синтаро, Ямакава Масао, Мисима Юкио сияқты көптеген жазушылар сол кезеңдегі адамдардың ішкі жан дүниесіндегі психологиялық өзгерістерді, соғыста жеңіліске ұшыраған жан күйзелістері мәселелерін кеңінен көтерген. Бұл мақалада Жапонияның сол кезеңде Аүниеге келген ең жарқын әдеби туындылары сипатталып, олардағы әлеуметтік өмірдің көрінісі және жапон бірегейлігі мәселелері зерттеледі.

Түйін сөздер: жапон бірегейлігі, жапон әдебиеті, соғыстан кейінгі Жапония.

Японская национальная идентичность не раз подвергалась изменениям поА влиянием Аругих стран. Кризисы, происходившие в стране, стави^и под угрозу традиционную идентичность коренных жителей. Особенно активно самоидентификация начала изучаться в послевоенные годы. В это время бурно развивалась классическая литература. Популярным стало писать реальные и негативные стороны послевоенной жизни простых японцев. Многие писатели того времени, такие как Оэ Кэндзабуро, Исихара Синтаро, Ямакава Масао, Мисима Юкио, показывали в своих произведениях психологические изменения человека, его переживания о поражении в войне, его цели и оценку происходящего вокруг. В данной статье описываются наибо^ее яркие произведения, в которых можно найти отражение развития социальной жизни послевоенной Японии и понимание идентичности японскими писателями.

Кмючевые слова: японская идентичность, японская митература, послевоенная Япония. 


\section{JAPANESE IDENTITY THROUGH THE EYES OF JAPANESE WRITERS (II HALF OF XX CENTURY)}

The national identity - one of the components of human identity, associated with their perceived belonging to a particular ethnic group or nation. The national identity is not identical with the concepts of nationality and citizenship, although they can be factors that have a strong influence on it. The interpretation of the identity of a nation is not only attribution itself to certain civilized community, but also the vision of its place in the system of international relations. [1] In this article, the development of the national identity of Japan will be treated through Japan literature. Therefore, we have been carefully analyzed the works of authors of the second half of XX-th century. The leading theme of many authors was dissatisfaction, loss of purpose and humility of defeat. The social stagnation, loose morals found in the works of most writers, including Oe Kenzaburo, Shintaro Ishihara, as well as many others - Yamakawa Macao, Yukio Mishima. For example, take the product of the Mishima. «Confessions of a Mask», where the autobiographical hero whose teenage years comes at a time of war, shows a range of adverse reactions to the war». And here in front of our eyes appeared the consequences of yesterday's bombing. Pedestrian bridge over the railway tracks were all made to stretchers with the wounded. $<\ldots>$ I felt like a fire erupted in my soul. This exhibition misfortunes gave me the courage to make yourself strong. I felt the lift, the excitement that cause revolutions «[2.27]. This reaction has been repeatedly featured in many works of the twentieth century. «During the war years it became fashionable ecstasy death on the battlefield, and I sympathized with this craze with all my heart. If I was lucky enough to fall «hero's death», so little befitting my humble person, I would lay in the grave itself and gleefully laughing at fooled Life. However, if you heard the sirens roar, I quickly rushed to the shelter of all «[2.32]. Pay special attention to the last words. The hero does not spare himself and others, he openly describes the very real and dire events of the war. For example, he describes poignantly state campaign: «Since the beginning of the war in the country, a wave of sanctimonious stoicism. I reached it, and the walls of our school. What we were looking forward to the day when we come to high school students, and finally obtain the right to wear long hair! But, these hopes were not realized. Gone and liberties with bright socks. More lessons allotted for military training; every day there were another innovation, 
one more absurd than the other «[2.34]. Maverick, not perceiving themselves as part of the state (for the Japanese, known for their «collectivist» spirit, especially due harsh propaganda efforts during the war, quite unexpectedly), he drags to death, but not eager to go to war and defend Japan. After receiving the summons, he passes a medical examination in the countryside, where, in comparison with healthy peasants, frail Tokyo person certainly look unhealthy, gives a cold as tuberculosis and successfully «decimated» by the army (the episode, by the way, autobiographical): "Coming out of the gate part, I sprinted ran down the hill, to the piedmont village. It was a windy winter day. As the plant at the time of the alarm, the legs carried me quickly away from danger - no matter where, if only out of death ... «[2.39]. The attitude to the war and the defeat of the coming general contains a whole range of conflicting emotions - escapism, apathy, replacement: «For breakfast also talked about the air raid - the first for the current month. As the siren was provisional, everyone was optimistic, decided that nothing terrible has happened. Yes, even if somewhere and bombed - I was quite touched. Even in the absence of my parents' house burns down with the whole family in the bargain, what do I care? I was not some special fanatic. So thoroughly were analyzed works of writers of the second half of XX-th century. all of us at that time considerably weakened the power of imagination, for every day it could be something like that, how would not have guessed and the most sophisticated fantasy. Where it was easier to imagine the death of relatives, than to imagine that the Ginza showcases newly filled rows of bottles with foreign labels, and the evening sky reflections shine neon signs «[2.42]. However, the main motive is becoming solipsistic self-removal, escapism [3]. These excerpts were taken as an example, since this attitude was present not only the main character, but also the rest of the population.

Second, after the "Confessions" main "bestseller" Mishima "Golden Temple" (1956) also shows the reaction of ordinary people to fight and defeat it. Mizoguchi, the protagonist of "Temple", concentrating on their tragic relationship with overwhelming beauty (he dreams to burn from the bombing of a fire to the Golden Temple, the captives and feeding it to their embodiment of absolute beauty, so as to get rid of the dictates of beauty and in death, to approach it), passing focuses and historical metamorphosis, becoming the backdrop for his personal existential agonizing. The main thing was, of course, "ending the war" - so this term ("syusen") the Japanese, both then and now seek to maximize displace more historically correct token "lost the war" ( "haysen") [4]: "The war is over. Listening to the shop floor, as a read out on the radio imperial decree on cessation of hostilities, I thought only of the Golden Temple. <...> In Tokyo, after hearing about the end of the war, a crowd of people with tears rushed to the imperial palace $<\ldots>$. The temple was far superior military collapse and the nation's tragedy. $<\ldots>$ The defeat in the war meant for me to dive into the depths of despair - for one reason only. I still see as a reality unbearably bright sun August 15 and forty-five. They say the day collapsed all values; for me, on the contrary, it has revived an eternity, cheered for life and established in their rights. Eternity told me that the Golden Temple will always exist "[5.33]. Familiar already "Confession" escapism and almost deliberate indifference to the outside world in this novel, Mishima seemed amplified. As for the relationship to the emperor, the heir to the goddess Amaterasu, then there are obvious traces of Shinto - not archaic, but alive and relevant for the majority of the Japanese middle of the last century. So, on the day when the Emperor had read the decree on the end of the war (the event itself out of the ordinary, because the emperor is traditionally communicated with citizens through written decrees and live contact with him almost completely excluded from the Japanese life - his voice heard forbidden , from the look on it could cause blindness, and even personal doctor touched the monarch in the gloves of the body). [6] Mizoguchi with friends before going to bed, "prays for the health of the emperor and for the repose of those killed in the war," and their abbot for another class chooses a koan the interpretation, speaking of the need to "unlimited self-denial" as "true path Bodhisattva."

It appears in the "Temple" and the theme that within a decade will be fundamental for Mishima, namely the theme of entropy, decay of morals, depravity of the (opposed to the glorious bygone days when the emperor's face has not "clouded clouds" [5.36]). The defeat in the war, after the war, imposed on American Constitution and, most importantly, the emperor renunciation of his divine essence (that is, the main outcome of the war and the "discovery" of Japan) led by Mishima, to the fact that the ancient spirit of the traditional Japan was betrayed reigned times expansions and debauchery. No, to the ideological justification of the Mishima will come later as soon as it fixes "atmospheric phenomena": "I did not depart from Tsurukava and asked if he understood that our country is entering a new era and is even impossible to imagine what we are waiting for change. I am reminded of a story that all discussed 
in the school on the third day after the end of the war an officer, director of the factory, where we worked before, drove to his home a truck finished products, bluntly stating that he was going to sell on the black market. That's what I see before me this bold and cruel, with piercing gaze man goes straight course in the world of vice "[5.45].

Other authors also wrote about the difficult postwar life, the change of consciousness, although this time is typical for any country defeated in war. Since the mid-50s for the first time and there is rapidly gaining momentum works with elements of violence, which shows a strong lone hero or scored, a helpless young man. However, in both cases the characters are thrown out from society, separated from it, unnecessary social elements, which is inherent loneliness, fear of the outside world, internal helplessness. Already in the very first story writer is a so-called situation of "prison" or "solitary confinement", such a psychological state of a person when he is not able to take action (individual or collective) and cannot get out of the psychological impasse. This condition - is conclusion themselves, alienation, "deprivation of liberty". Existential boredom, lack of hope for the future (in the spirit of Camus) heroes writer Kenzaburo Oe materialized in asocial rebellion, the beginnings of which we find in the early stories of the writer. [6]

In 50-60-ies in Japan began to dominate new concepts and phenomena of social life - the modernization, industrialization, rapid economic growth, the theory of mass society, post-industrial society. As a result - the desire of the individual to escape from reality, a split personality and the loss of his "I". In Japan, it is now becoming known Oe Kenzaburo the same, and such writers as the Kaiko Ken, Abe Kobo. Ishikawa Tatsudzo. About them we can say that while these writers shared the views of the new radicalism of American writers and partially or completely torn from the "artistic" tradition of Japanese classics. Kobe Abe wrote the novels "Woman in the Dunes", "Burnt Card", "Man-box", etc .; Kaiko Ken story "Panic", "Giants and Toys", "Summer Darkness" (listed product refer to the end of 50th -.. Early 70- ies) dedicates the theme of human alienation from society and the loss of identity problem.

Roman Oe "late youth" was published in 1961 $\mathrm{m}$. The novel's hero falls in Tokyo and loses its true essence. Why is this happening to the hero of the novel, is why in the end, he mentally and physically degraded? Actually this is not only one main character and with millions of young Japanese immediately after the Second World War. In the preface to the Russian edition of the novel A. Majewski wrote that "the generation that Oe calls the" latecomers ", correctly be described as" deceived "...". Others literary, drawing parallels with the youth of the West at that time, according to the Japanese youth "lost." As a result, the youth of that time can be called a "deceived" and "late", and "lost". Hero "was late youth", as well as the Stranger (Camus novel "The Outsider"), cleaved and dismembered inside and but to society. This explains his endless throwing from one people to another: Sawada politics, left-extremists. lover, a friend, a Korean [7].

Rapidly evolving technological advances have led to the depersonalization of millions of Japanese to their concentration in large industrial centers. Isolation from their homes and living in Tokyo painful effect on the psychological state of its inhabitants. With the hero of Oe bird (novel "Personal experience") is all that happens. The same dissolution man in the big city of Tokyo giant leads to the phenomenon of "loss of cultural identity."

The story "Sakurajima" Haruo Umedzaki, which belongs to the first post-war generation of writers, art disillusioned and skeptical officer of the Navy, serving in the base located on the volcanic island of Sakurajima, close to Kagoshima, the southern tip of Kyushu island. Roman Osamu Dadze "Setting Sun" tells the story of a soldier returning from Manchukuo. Shohei Ooka was awarded the "Fire on the plain" Yomiuri Literary Award for his novel: on the Japanese-deserter who goes mad in the Philippine jungle. Yukio Mishima - also eminent postwar writer, well-known for his nihilistic manner of writing and committed suicide (seppuku). Mitsuaki Inoue in the 1980s wrote about the problems of the nuclear age, while Shusaku. Endo, a prominent representative of the "new third" portrayed the dilemma of religious Catholics in feudal Japan, kakure-kirisitan, as a basis for decisions spiritual problems. Yasushi Inoue also turned to the past, skillfully depicting people's lives in the historical novels of Inner Asia and ancient Japan. He received significant recognition Kobo Abe, belonged to the second post-war generation of writers, with his most famous work - Woman in the Dunes 1960. Ësikiti Furuya (refers to the «generation of introverts») wrote the psychodrama of the difficulties of urban residents who are forced to deal with the minutiae of everyday life. In 1988, the award was named Naoki Sandzyugo Shizuka Todo for «matures Summer» - a story about the psychology of the modern woman.

All of these writers - whatever the product for analysis, we do not have, no doubt, encounter complex, intertwined and confused conglomerate of ideas, concepts, beliefs, which they took, learn- 
ing from the West, China, and at the same time, not looking up from his Japanese roots. This Buddhism came to Japan, the first ever in China, and Confucianism, but the ethical standards which are largely Japanese life is arranged, and Christianity, which never managed to overcome in the XVII century, and Marxism, whose influence has been dominant for many years in Pasha Century [8].

Note that since the 80 s writers didn't write about extremism and fears beset Japanese. Also, the problem of the loss of his "I" is increasingly coming from the pages of literature in society. When life in Japan, after the horror of the post-war years has been on the right path of development and the general state of the country began to stabilize, the whole Japanese culture and identity look as in the West. The period of prosperity of the economy and raising the legs on all of Japanese society. This was a transition period and preparing the ground for refusal of "negative uniqueness" in favor of "positive uniqueness", which lasted more than 20 years from the mid 1960 $\mathrm{s}$ to the early $1980 \mathrm{~s}$ and eventually gave rise to the mass (positive) nihondzinron. Economic well-being and political stability, caused a new wave of demand for "culture and identity" in Japanese society, and the response to this demand of steel various positive options nihondzinron asserting the uniqueness and superiority of the Japanese socio-economic model.

\section{References}

1 Mel'vil' A.Yu. Politicheskiy atlas sovremennosti. Opyt mnogomernogo statisticheskogo analiza politicheskikh sistem sovremennykh gosudarstv. - M.: MGIMO-Universitet., 2007

2 Yukio Misima. Elektronnaya kniga Ispoved' Maski na sayte http://loveread.ec. - Eksmo, 2009. - 47 s.

3 Grigor'yev M.Yu. Problema poteri identichnosti v poslevoennoy yaponskoy literature //«Filologiya»// INION RAN. - 1996. - № 9.

4 Chantsev A. Povorot naborot v poslevoennoy Yaponii: Yu. Misima o voyne i mire // Novyy mir. - 2010. - 2.

5 Misima Yu. Zolotoy Khram / Per. s yap. G. Chkhartishvili. - SPb., «Severo-Zapad», 1993. - 97 s.

6 Gudkov L. Negativnaya identichnost'. - M.: «Novoe literaturnoe obozrenie», «VTsIOM-A», 2004. - S. 9-10.

7 Aleksandr Bukh. Yaponiya: natsional'naya identichnost' i vneshnyaya politika: Rossiya kak Drugoe Yaponii. // Novoe literaturnoe obozrenie. - 2014.

8 Gregor'yev M.Yu. Molodoe pokolenie v poslevoennoy yaponskoy literature // http://cheloveknauka.com/molodoe-pokolenie-v-poslevoennoy-yaponskoy-literature 